\title{
LAGU KEAGAMAAN HINDU DALAM PEMBENTUKAN KARAKTER SISWA PAUD HINDU AMERTHA YULIA GANESHA KABUPATEN KARANGASEM
}

\author{
Application of Hindu Religius Songs Students of PAUD Hindu Amertha Yulia Ganesha \\ Karangasem Regency
}

\author{
I Wayan Mertayasa \\ Pengelola Pratama Widya Pasraman Amertha Yulia Ganesha \\ Email: iwayanmertayasaayg@gmail.com
}

\begin{abstract}
The problems associated with Hindu student moral PAUD Hindu Amertha Yulia Ganesha, among others : (1) the prosedures for the implementation of the Gayatri Mantra has not been accomplished in accordance with the rules set out in the guidance kramaning worship, characterized by the students always joke in implementing the gayatri mantram, (2) the behavior of students who dared insult teacher, (3) fights between students, (4) bullying, (5) the awareness of students to maintain the cleanliness of the toilets is still lacking, and (6) students still throw rubbish indiscriminately. To solve a very complex problem that the education value of the character and spirituality in school is very precise taught through the implementatition of the concept of the doctrine of Hindu Religius Song. Because the doctrine of Tri Hita Karana build a sense of life balance and harmony with God, with fellow humans and with the natural environment. From this background it can be formulated several problems, namely: what is the purpose and function, how strategy and implementation impact Hindu religius songs is based on the teaching of character education of PAUD Hindu Amertha Yulia Ganesha Karangasem regency? The third formulation of the problem of this study was to determine purpose and function. Implementation strategies and the impact of Hindu Religius Songs in Hindu students PAUD Hindu Amertha Yulia Ganesha, Karangasem regency.

This study uses the theory of the behavioristic teory and contructivist theory as a basis for making detailed statemens to dissect the problem formulation. This type of research conducted by the author is a qualitative research method qualitative descriptive approach with the technique of collecting data through observation, interviews and document research, then processed and analysed by qualitative descriptive narrative.

Based on the results obtained by analysis of a finding that the Hindu religius songs is based on the teaching of character education of PAUD Hindu Amertha Yulia Ganesha Karangasem regency is to assist the development of learners, especially Hindus to become more fully human and conscious of the responsibility for self, others, the universe, and God. Whereas its function is overcome demoralization Hindu student. The implementation strategy of character education based on the teachings of Parahyangan is habituation implement Gayatri Mantram, habituation prayer on the holy day of Purnama and Tilem and the kingdom of Saraswati Day, the implementation strategy of character education throught the implementation of the teaching. Habituation greeting panganjali. The impact of Hindu religius songs is based on the teaching of character education of PAUD Hindu Amertha Yulia Ganesha Karangasem regency are student willing to work hard, have discipline became a believer, being soft-hearted, being responsible, be tolerant, be honest, be respectful of time, be polite, courteous and respect.
\end{abstract}

Keywords : Hindu Religius Song, Character Education 


\begin{abstract}
ABSTRAK
Masalah-masalah yang berkaitan dengan karakter siswa Hindu PAUD Hindu Amertha Yulia Ganesha antara lain: (1) tata cara sembahyang pengucapan Gayatri Mantram, siswa banyak bercanda dalam mengucapkan Gayatri Mantram (2) perilaku siswa yang berani melawan nasehat guru (3) siswa yang suka berkelahi dengan teman sebayanya (4) pencurian (5) kesadaran siswa menjaga kebersihan WC kurang, (6) siswa membuang sampah dengan sembarangan. Untuk mengatasi masalah yang sangat komplek tersebut maka pendidikan karakter perlu ditumbuhkembangkan melalui beraneka metode salah satunya adalah lagu keagamaan Hindu. Melalui lagu keagamaan Hindu yang dibuat khusus mengandung nilainilai pendidikan agama Hindu, seperti: menjaga hubungan yang baik antara manusia dengan Ida Sang Hyang Widhi Wasa, hubungan yang baik antara manusia dengan sesama manusia, dan manusia dengan alam semesta yang disebut dengan konsep Tri Hita Karana. Dari latar belakang tersebut maka dapat dirumuskan beberapa permasalahan yaitu : mengapa lagu keagamaan Hindu diterapkan dalam membentuk karakter siswa, apakah fungsi lagu keagamaan Hindu, bagaimanakah proses penerapan lagu keagamaan Hindu di PAUD Hindu Amertha Yulia Ganesha? Dari ketiga rumusan masalah tersebut, tujuan penelitian ini adalah untuk mengetahui lagu keagamaan Hindu dalam membentuk karakter siswa, fungsi lagu keagamaan Hindu, dan proses penerapan lagu keagamaan Hindu di PAUD Hindu Amertha Yulia Ganesha, kabupaten Karangasem. Penelitian ini menggunakan teori behavioristik dan teori fungsional struktural sebagai dasar untuk membuat pertanyaan-pertanyaan secara terperinci untuk membedah rumusan masalah. Jenis Penelitian yang dilakukan adalah penelitian kualitatif dengan metode pendekatan deskriptif kualilatif dengan teknik pengumpulan data melalui observasi, wawancara, dan studi dokumen, kemudian diolah dan dianalisis secara naratif dengan pendekatan deskriptif kualitatif.

Berdasarkan hasil analisis diperoleh suatu temuan bahwa tujuan penerapan lagu keagamaan Hindu untuk membangun karakter siswa PAUD Hindu Amertha Yulia Ganesha adalah untuk membantu perkembangan peserta didik khususnya yang beragama Hindu untuk menjadi manusia yang lebih utuh dan sadar akan tanggung jawab terhadap dirinya, orang lain, alam semesta dan Tuhan Yang Maha Esa. Strategi penerapan lagu keagamaan hindu untuk membangun karakter adalah dengan pembiasaan menyanyikan lagu tersebut dan mengimplementasikannya dalam pembelajaran di PAUD dengan pembiasaan melakukan puja tri sandya/mengucapkan Gayatri Mantram, pembiasaan sembahyang pada hari suci Purnama dan Tilem serta hari raya Saraswati, pembiasaan mengucapkan salam Om Swastyasu. Menjaga kebersihan areal lingkungan sekolah, dampak penerapan lagu pendidikan karakter bagi siswa PAUD Hindu Amertha Yulia Ganesha adalah siswa mampu bekerja keras, memiliki sikap disiplin, menjadi orang beriman, menjadi orang berhati lembut, menjadi orang berhati lembut, menjadi orang bertanggung jawab, bersikap tenggang rasa, bersikap jujur, bersikap menghargai waktu, bersikap sopan, santun dan hormat.
\end{abstract}

Kata Kunci : Lagu Keagamaan Hindu, Karakter Siswa

\section{PENDAHULUAN}

Agenda pendidikan tahun 2030, komitmen dunia untuk mendukung kesempatan belajar sepanjang hayat untuk semua, pada seluruh lingkungan dan tingkat pendidikan (Kemdikbud, 2016, v). Kesempatan belajar dari tingkat anak usia dini sampai dengan pendidikan orang dewasa. Setiap manusia pada hakikatnya, berhak mendapatkan kesempatan belajar yang sama dan merata. Kesempatan belajar, merupakan peluang pendidikan yang dimiliki oleh setiap manusia agar bisa bertahan hidup dan menciptakan pekerjaan bagi dirinya sendiri dan orang lain. 
Realita di lapangan sangat bertolak belakang dengan realita yang ada. Orang tua sering kali melupakan bahwa, ada caracara yang lebih mudah dan praktis untuk meningkatkan potensi kecerdasan anaknya. Cara mudah itu adalah bermain dan bernyanyi. Orang tua kerap kali melarang anaknya untuk bermain dan bernyanyi. Bermain atau bernyanyi dirasakan hanya membuang-buang waktu, kotor bahkan ketika melihat anaknya banyak bersuara dianggap menciptakan kegaduhan dan mengganggu konsentrasi orang tuanya. Faktanya, beberapa permainan yang dibubuhi ide-ide kreatif penciptanya seperti dikolaborasikan dengan nyanyian memiliki manfaat yang sangat luar biasa. Manfaatnya adalah mampu memaksimumkan potensi kecerdasan anak. Selain itu, permainan yang dibubuhi dengan nyanyian adalah cerminan perkembangan peserta didik. Melalui Permainan dan nyanyian peserta didik belajar mengendalikan diri sendiri, melatih konsentrasi, penguasaan kosa kata dan bahasa, serta belajar berkomunikasi. Selain itu, peserta didik juga dapat melakukan berbagai kegiatan yang merangsang dan mendorong kepribadian anak. Aspek nilai agama dan moral, keterampilan/ psikomotorik, kecerdasan bahasa, emosi, maupun social dapat terasah dengan baik melalui kegiatan bermain dan bernyanyi.

Dibubuhkannya beberapa kreativitas dalam lagu, berdampak sangat positif bagi perkembangan nalar peserta didik. Peserta didik dapat memuaskan tuntutan dan kebutuhan perkembangannya dalam dimensi : nilai agama dan moral, motoric kognitif, kreativitas, bahasa, emosi, seni, dan karakter lainnya. Lagu itu ibarat sebuah kartu, yang mana siapa saja sudah mengetahui gambar apa dibaliknya, lagu pun sudah menjadi hal yang umum diketahui sebagai media belajar yang menyenangkan. Lagu yang mengandung unsur pendidikan memungkinkan anak untuk belajar secara alami, santai dan itulah yang cocok bagi peserta didik. Pengalaman yang diperoleh lewat media lagu dapat meningkatkan IQ anak, meningkatkan rasa percaya dirinya, dan dapat memberikan awal yang lebih baik dalam proses pembelajarannya. Beberapa manfaat lagu pendidikan antara lain: pertama, lagu pendidikan mampu memberikan kesempatan bagi peserta didik untuk hidup dan berucap dengan kata-katanya sendiri. Kalimat dalam lagu menunjukkan bagaimana peserta didik bersikap dan bagaimana peserta didik itu berpikir. Hal tersebut merupakan cerminan kepribadian peserta didik, bukanlah duplikat dari orang tua/pendidik secara utuh. Lebih dari itu, peserta didik berhak atas diri dan kehidupannya. Kedua, mengijinkan peserta didik dan segala yang ada pada diri peserta didik agar tetap unik, indah, dan berbeda. Istilah lainnya, membiarkan peserta didik menjadi dan menerima dirinya sendiri. Jiwa Peserta didik jangan dibebani dengan target dan kehendak pribadi orang tua maupun guru. Keunikan pada diri peserta didik, janganlah dibunuh atau dibatasi, hanya demi memenuhi standar mayoritas yang jamak berlaku dalam masyarakat. Harapan anak kemungkinan bersebrangan dengan idealisme orang tua, guru, dan orang dewasa disekitarnya. Ketiga, berilah anak kesempatan untuk berusaha secara mandiri dan belajar dari kesalahan yang diperbuatnya. Trial and Error (mencoba dan salah) ada kalanya merupakan alternatif bijak yang menawarkan pengalaman baru kepada peserta didik. Melalui lagu-lagu yang mengandung unsur pendidikan, peserta didik akan belajar menemukan dan memahami sesuatu setelah melewati serangkaian kesalahan demi kesalahan. Salah satu solusi yang digunakan memotivasi peserta didik agar menyenangi tema pelajaran agama Hindu adalah menggunakan media lagu keagamaan yang dibubuhi dengan nilai-nilai pendidikan karakter terutama yang berkenaan dengan peningkatan aspek agama dan moral. Penerapan lagu keagamaan Hindu dalam pembelajaran PWP Amertha Yulia Ganesha, diduga akan dapat digunakan sebagai alternatif pemecahan masalah rendahnya penguasaan materi keagamaan Hindu terutama istilahistilah Hindu dan nilai karakter agama dan moral peserta didik PWP Amertha Yulia Ganesha. Dalam penelitian ini, pengujian lagu keagamaan Hindu terhadap penguasaan istilah-istilah agama Hindu dan nilai karakter agama dan moral peserta didik PWP Amertha Yulia Ganesha, Br. Dinas Kubakal, Desa 
Pempatan, Kecamatan Rendang, Kabupaten Karangasem. Perumusan masalah dalam penelitian ini adalah sebagai berikut. (1) Mengapa lagu keagamaan Hindu diterapkan dalam membentuk karakter siswa PAUD Hindu Amertha Yulia Ganesha Kabupaten Karangasem?, (2) Apakah fungsi lagu keagamaan Hindu dalam pembentukan Karakter siswa PAUD Hindu Amertha Yulia Ganesha Kabupaten Karangasem?, (3) Bagaimana proses penerapan lagu keagamaan Hindu di PAUD Hindu Amertha Yulia Ganesha?

Tujuan penelitian ini adalah untuk membahas dan mengetahui penerapan lagu keagamaan Hindu dalam pembentukan karakter siswa PAUD Hindu Amertha Yulia Ganesha, Banjar Dinas Kubakal, Desa Pempatan, Kecamatan Rendang, kabupaten Karangasem. Dari penelitian yang dilakukan, diharapkan masyarakat dan para orang tua siswa khususnya mampu memahami betapa pentingnya penerapan lagu keagamaan Hindu yang berisikan materi-materi agama Hindu dasar dalam pembentukan karakter anak usia dini.

\section{KAJIAN PUSTAKA, DESKRIPSI KONSEP, LANDASAN TEORI, KERANGKA BERPIKIR DAN MODEL PENELITIAN}

\subsection{Kajian Pustaka}

Kajian pustaka dilakukan terhadap penelitian sebelum berupa referensi yang relevan dan memiliki kesesuaian dengan penelitian ini. Tujuannya adalah untuk menyesuaikan relevansi dan memperoleh data secara objektif berupa kepustakaan serta mempermudah dalam mengenal, menganalisis, memahami, dan objektivasi terhadap permasalahan yang akan diteliti. Ada beberapa sumber buku atau karya ilmiah yang dipakai sebagai acuan penelitian ini, buku pertama yang digunakan adalah karya Ahmad Susanto (2015) dalam bukunya "Bimbingan Konseling di Taman Kanak-Kanak" menyatakan bahwa taman kanak-kanak (TK) merupakan lembaga pendidikan dan sebagai tempat penyelenggaraan pendidikan bagi anak usia dini, serta diharapkan dapat mengembangkan kompetensi siswanya yang meliputi perkembangan akademis, keterampilan sosial, dan memiliki kemandirian. Program bimbingan dan konseling perlu dilakukan di TK tujuannya untuk memberikan bantuan kepada anak dalam rangka upaya membentuk kepribadian yang baik pada anak, memperkenalkan lingkungan, dan merencanakan masa depan bagi anak. Guru sebagai tenaga profesional memiliki tugas utama untuk mendidik, mengajar, dan membimbing peserta didik pada pendidikan anak usia dini. Tugas guru sebagai pembimbing yaitu melihat dan mengamati karakteristik anak serta mengarahkan anak untuk dikembangkan sesuai dengan potensi yang dimilikinya. Buku dari Ahmad Susanto tersebut memiliki korelasi yang relatif sama dengan penelitian ini. Namun demikian, dalam bukunya hanya sebatas menjelaskan tentang pentingnya peran guru dan orang tua dalam memberikan bimbingan pada anak usia dini. Sedangkan dalam penelitian ini menekankan pada upaya guru membentuk karakter anak melalui pendidikan agama Hindu, seberapa pentingnya pendidikan agama Hindu dalam membentuk karakter anak di PAUD Hindu Amertha Yulia Ganesha melalui lagu keagamaan Hindu.

\subsection{Deskripsi Konsep}

Menurut tim penyusun (2009:8) konsep memberi batasan atau beristilahan dalam suatu penelitian, karena itu menunjukkan objek penelitian, baik material maupun formal. Konsep yang perlu dideskripsikan adalah variabel-variabel atau komponen yang ada dalam judul penelitian.

\subsubsection{Penerapan}

Penerapan mengandung pengertian pemakaian suatu cara atau metode atau juga suatu sistem untuk mempermudah pemahaman. Menurut Kamus Besar Bahasa Indonesia (KBBI, 1448:2008) menyatakan bahwa penerapan adalah proses, cara, perbuatan menerapkan, sedangkan menurut beberapa ahli berpendapat bahwa penerapan adalah suatu perbuatan mempraktekkan suatu teori, metode, dan hal lain untuk mencapai tujuan tertentu dan untuk suatu kelompok/ 
golongan yang telah terencana dan tersusun sebelumnya. Dari penjelasan di atas tentang pengertian penerapan yang telah dijabarkan, maka yang dimaksud dalam penelitian ini, peneliti lebih menekankan pada penerapan pendidikan agama Hindu baik dilakukan secara individu atau kelompok dengan maksud untuk mencapai tujuan yang telah dirumuskan.

\subsubsection{Pendidikan Agama Hindu}

Poetbakawatja dan Harahap tahun 1981 (dalam Indah, 2015:19) mengartikan pendidikan sebagai suatu perbuatan dan usaha dari generasi tua untuk mengalihkan pengetahuannya, pengalamannya, kecakapannya, dan keterampilannya kepada generasi muda sebagai usaha menyiapkan agar dapat memenuhi fungsi hidupnya baik jasmani maupun rohani. Menurut PHDI dalam himpunan keputusan seminar kesatuan tafsir terhadap aspek-aspek agama Hindu (1-XV, 1998: 23-24) dijelaskan bahwa pendidikan agama Hindu dapat berlangsung atau dilaksanakan melalui dua jalur antara lain: (1) Pendidikan agama Hindu di luar sekolah merupakan suatu upaya untuk membina pertumbuhan jiwa masyarakat dengan ajaran agama Hindu itu sendiri sebagai pokok materinya; (2) Pendidikan agama Hindu di sekolah ialah suatu upaya untuk membina pertumbuhan jiwa dan raga anak didik sesuai dengan ajaran agama Hindu.

Dari uraian yang telah disampaiakan di atas, maka dapat disimpulkan bahwa pendidika agama Hindu mampu meningkatkan karakter anak didik PAUD Hindu Amertha Yulia Ganesha. Hal ini menunjukkan bahwa dalam tujuan pendidikan searah dengan tujuan agama itu sendiri. Moksartam Jagaddita Ya Ca Iti Dharma, ilmu pengetahuan umum (guna widya) sangat diperlukan untuk dipelajari agar mendapatkan kebahagiaan dunia akhirat.

\subsubsection{Lagu}

Lagu menurut Kamus Lengkap Bahasa Indonesia merupakan berbagai irama yang meliputi suara instrumen dan bernyanyi. Lagu akan lebih indah jika diaransemen dengan musik yang sesuai. Musik dan lagu merupakan suatu kombinasi yang tidak terpisahkan. Makna lagu akan sampai ke penikmat/pendengarnya jika musiknya seirama dengan lagu tersebut. Tim Gunung Djati (2008:6-7) menyebutkan bahwa musik adalah ekspresi manusia terhadap suatu bentuk keindahan yang diwujudkan dalam banyak bentuk. Seni adalah bagian dari penciptaan manusia, dimana Tuhan Yang Maha Esa menyebutkan manusia adalah sebagai sebaik-baiknya bentuk.

Lagu dan musik merupakan suatu kombinasi yang seringkali dinyanyikan atau dibawakan oleh seseorang baik dilakukan sendiri atau berkelompok dengan menggunakan alat untuk mencapai tujuan tertentu. Hal senada juga disampaikan oleh Jasmine (2005:8), yang menjelaskan bahwa musik dan lagu merupakan sesuatu yang dibuat untuk memperoleh kesenangan. Lagu dan musik merupakan luapan ekspresi yang dibuat atau diucapkan oleh seseorang atas keinginannya sendiri atau mengadopsi yang sudah ada dalam rangka mengungkapkan konflik dirinya yang disadari atau tidak disadari guna memperoleh kesenangan atau kepuasan. Dari beberapa pendapat di atas, dapat disimpulkan bahwa musik dan lagu sangat penting bagi peserta didik, karena dapat memberikan rasa senang kepada peserta didik. Melalui musik dan lagu, peserta didik berusaha memiliki keinginan dan mencapai keinginannya. Semangat kompetisi peserta didik biasanya akan terpacu ketika melontarkan lagu/yell yang memotivasi. Membawakan lagu bersama-sama dengan peserta didik/kegiatan bernyanyi dapat meningkatkan kedekatan antara pendidik dengan peserta didik. Pendidik akan menjadi sosok yang disegani, disayangi dan digandrungi tatkala pendidik tersebut dapat mengambil hati peserta didiknya. Hal senada juga diungkapkan oleh Munnir (2011:25) yang mengungkapkan bahwa beraktivitas bersama-sama peserta didikbisa menjadi sarana yang bagus untuk membangun kedekatan.

\subsubsection{Lagu Keagamaan Hindu}

Menurut Kamus Bahasa Indonesia, lagu merupakan ragam suara yang berirama 
dalam percakapan, bernyanyi, atau membaca. Secara umum, yang dimaksud dengan lagu anak adalah lagu yang dinyanyikan untuk anak, dan lagu untuk dinyanyikan oleh anak. Sedangkan musik adalah suara yang disusun sedemikan rupa sehingga mengandung irama, lagu dan keharmonisan terutama suara yang dihasilkan dari alat-alat yang dapat menghasilkan bunyi-bunyian.

Lagu keagamaan Hindu yang diperuntukkan bagi anak usia dini merupakan sebuah alternatif yang bisa digunakan untuk meningkatkan rasa kecintaan anak terhadap agama yang dianutnya. Selama ini, orang tua jarang sekali memperkenalkan nilainilai agamanya kepada peserta didik. Hal ini dikeranakan karena berbagai faktor salah satunya adalah kesibukan para orang tua. Padahal, jika nilai-nilai agama Hindu dipekenalkan dari sejak dini maka harapan orang tua untuk menjadikan putra/inya untuk menjadi anak yang suputra pasti akan tercapai. Nilai-nilai agama Hindu, tidak hanya menanamkan nilai-nilai karakter, namun etika dan moral juga banyak diajarkan melalui pendidikan agama Hindu.

\subsubsection{Karakter Anak}

Dalam Kamus Besar Bahasa Indonesia, karakter diartikan sebagai sifat-sifat , kejiwaan, akhlak atau budi pekerti menjadi ciri khas seseorang (Zulfajri dan Senja, 2003:422) (dalam Paramartha, 2015:8). Adapun Hernowo mengartikan karakter sebagai watak, sifat, atau hal-hal yang sangat mendasar pada diri seseorang. Karakter juga bisa diartikan sebagai watak, tabiat, atau akhlak yang membedakan seseorang dengan orang lain (Hermowo, 2004:175) (dalam Paramartha, 2015:9). Menurut Gulo (1992:13) karakter adalah kepribadian ditinjau dari titik tolak etis atau moral misalnya kejujuran seseorang, dan biasanya mempunyai sifatsifat relatif tetap. Lalu menurut Buya Hamka (dalam Paramartha, 2015:9) mengatakan bahwa karakter adalah kualitas atau kekuatan mental dan moral, akhlak atau budi pekerti individu yang merupakan kepribadian khusus yang membedakan dengan individu lain.

\subsubsection{Lembaga Pesraman Hindu}

Berdasarkan Peraturan Menteri Agama Republik Indonesia Nomor 56 Tahun 2014, dalam rangka membentuk masyarakat Hindu yang mempunyai kemampuan dan pengetahuan dalam bidang Agma Hindu serta berkualitas dan berdaya saing, dibutuhkan Pendidikan keagamaan Hindu. Pendidikan keagamaan Hindu merupakan lembaga pendidikan Agama Hindu yang berada pada jalur pendidikan formal dan non formal dalam suatu wadah yang disebut dengan Pasraman. Satuan pendidikan Pratama Widya Pasraman (PWP) merupakan pendidikan anak usia dini diikuti oleh anak yang berusia di bawah 6 (Enam) tahun. Satuan Pendidikan Adi Widya pasraman merupakan pendidikan dasar tingkat Sekolah dasar (SD) yang terdiri atas 6 (enam) tingkat. Satuan pendidikan Madyama Widya Pasraman merupakan pendidikan dasar tingkat Sekolah Menengah Pertama (SMP) yan terdiri atas 3 (tiga) tingkatan. Satuan Pendidikan Utama Widya Pasraman merupakan pendidikan tingkat Sekolah Menengah Atas yang terdiri atas 3 (tiga) tingkat. Satuan pendidikan Maha Widya Pasraman merupakan pendidikan tingkat Tinggi.

Lembaga Pasraman memiliki tujuan untuk menanamkan kepada peserta didik/ brahmacari agar memiliki sradha/keyakinan dan bhakti kepada Brahman (Tuhan Yang Maha Esa), dan mengembangkan kemampuan, pengetahuan, sikap dan keterampilan Brahmacari untuk menjadi ahli ilmu agama Hindu dan memiliki ilmu pengetahuan, cakap, kreatif, mandiri dan menjadi warga Negara yang demokratis serta bertanggungjawab terhadap pemahaman Weda. Pendirian lembaga Pasraman Formal maupun Non formal wajib memperoleh ijin penyelenggaraan dari Direktur Jenderal. Memperoleh Rekomendasi dari Kementerian Agama Kabupaten dan Kantor Wilayah Kementerian Agama provinsi masing-masing. Pendirian Pasraman formal dan non formal harus memenuhi persyaratan administrasi, persyaratan teknis dan kelayakan pendirian. Persyaratan administrasi lembaga pasraman, paling sedikit memuat tentang badan hukum 
dari lembaga yang bersangkutan, memiliki struktur organisasi, anggaran dasar dan anggaran rumah tangga (AD/ART), dan pengurus pasraman. Melampirkan pernyataan dan bukti kesanggupan untuk membiayai lembaga pendidikan tersebut untuk jangka waktu paling sedikit 3 (tiga) tahun.

\subsubsection{PAUD Hindu}

Pendidikan anak usia dini berkembang pesat, hal ini ditandai dengan terus bertambahnya jumlah lembaga PAUD. Taman Kanak-kanak (TK), Raudatul atfal (RA), kelompok Bermain (KB), Taman Penitipan Anak(TPA), Pratama Widya Pasraman(PWP), dan PAUD sejenis lainnya dengan nama yang bervariasi banyak bermunculan. Hal ini juga sebagai bukti meningkatnya kesadaran orang tua dan guru tentang pentingnya pendidikan anak sejak dini. Banyak orang tua maupun guru telah memahami pentingnya masa emas (golden age) perkembangan pada usia dini. Sebagaimana penting masa sensitifnya semua potensi yang dimiliki anak untuk berkembang. Untuk itu perlu dukungan lingkungan yang kondusif bagi perkembangan potensi yang dimiliki anak. Anak didik (anak usia dini) menduduki posisi penting dan menjadi acuan utama dalam pemilihan pendekatan, model, dan metode pembelajaran. Hal yang perlu diingat dari sisi anak adalah PAUD, yang dalam hal ini adalah PAUD bernuansa Hindu/PWP. Fungsi PAUD bernuansa Hindu hampir sama dengan PAUD sejenis lainnya hanya saja, nilai keagamaan Hindu serta aspek nilai agama dan moralnya yang lebih banyak ditekankan. Fungsi PAUD Hindu/PWP yaitu untuk membantu mengembangkan semua potensi anak (niali agama dan moral, fisik, bahasa, intelektual/kognitif, emosi, dan sosial). Meletakkan dasar kearah perkembangan sikap, pengetahuan, keterampilan, dan daya cipta untuk menyesuaikan diri dengan lingkungannya dan untuk pertumbuhan dan perkembangan selanjutnya.

Secara umum, tujuan pendidikan anak usia dini adalah mengembangkan berbagai potensi anak sejak dini sebagai persiapan untuk hidup dan dapat menyesuaikan diri dengan lingkungannya. Kertamuda (2015:10) menjelaskan bahwa Pendidikan Anak Usia dini/lembaga PAUD sejenis pada hakikatnya ialah pendidikan yang diselenggarakan dengan tujuan untuk memfasilitasi pertumbuhan dan perkembangan anak secara menyeluruh atau menekankan pada pengembangan seluruh aspek kepribadian anakuntuk membentuk karakter anak. Dengan demikian perlunya lembaga PAUD/PWP, karena anak yang merasakan pendidikan sejak usia dini mempunyai perbedaan yang sangat mencolok dari pada anak yang kurang mendapat perhatian tentang pendidikan. Seperti halnya anak yang sejak dini telah dilatih untuk berdoa, untuk berakhlak mulia, untuk belajar, mengucapkan gayatri mantam maka akan terbentuk karakter Hindu pada anak tersebut.

\subsection{Model Penelitian}

Model penelitian merupakan model konseptual tentang bagaimana teori berhubungan dengan berbagai faktor yang telah diidentifikasi sebagai masalah yang terpenting. Menurut Tim Penyusun (2010:8) model penelitian merupakan abstraksi dan sintesis antara teori dan permasalahan penelitian yang digambarkan dalam bentuk gambar (bagan, grafik, dan lain-lain). Adapun kerangka berpikir dalam usulan penelitian ini dapat digambarkan dengan model penelitian sebagai berikut:

\section{Model Penelitian}

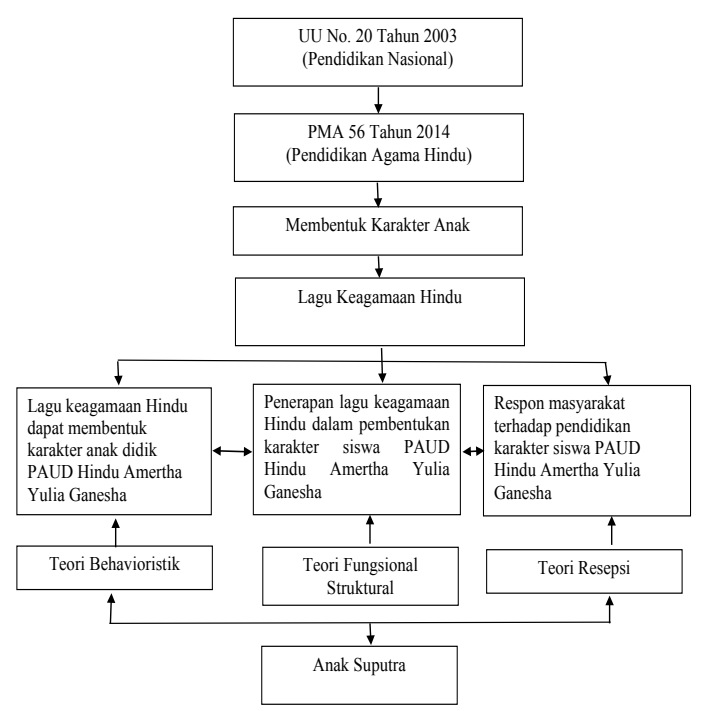


Penjelasan :

Dari skema di atas menunjukkan bahwa di dalam Undang-undang Nomor 20 Tahun 2003 terdapat tujuan pendidikan nasional yang berisi tentang perlunya mengembangkan potensi peserta didik agar memiliki kecerdasan, kepribadian, dan akhlak mulia. Pendidikan diharapkan tidak hanya bertujuan untuk menjadikan peserta didik pintar dan cerdas saja, tetapi memiliki karakter yang mulia.

Sesuai dengan PP 55 Tahun 2007 pasal 13 adalah pendidikan agama dapat memberikan pengetahuan, membentuk sikap, kepribadian, dan keterampilan peserta didik dalam mengamalkan ajaran agamanya. Oleh karena itu, pendidikan agama Hindu sangat penting diberikan mulai sejak usia dini, agar terbentuknya karakter yang baik. Salah satunya yang dilakukan pada PAUD Hindu Amertha Yulia Ganesha, dimana lagu keagamaan Hindu memiliki peran dalam menumbuhkan karakter siswa PAUD Hindu Amertha Yulia Ganesha.

Pada penelitian ini, hal yang diteliti mengkhusus pada (1) mengapa lagu keagamaan Hindu dalam pembentukan karakter siswa PAUD Hindu Amertha Yulia Ganesha, (2) apakah fungsi lagu keagamaan Hindu dalam pembentukan karakter siswa PAUD Hindu Amertha Yulia Ganesha, (3) bagaimana proses penerapan lagu keagamaan Hindu dalam pembentukan karakter siswa PAUD Hindu Amertha Yulia Ganesha.

\section{METODE PENELITIAN}

Metode penelitian sangatlah penting digunakan untuk kegiatan penelitian dalam berbagai bidang ilmu pengetahuan. Agar hasil penelitian dapat dipertanggungjawabkan secara ilmiah, maka metode yang akan dikaji sehingga mampu menghasilkan data objektif. Dalam penyusunan penelitian ini beberapa metode yang digunakan yaitu: Rancangan Penelitian, Lokasi Penelitian, Jenis dan Sumber Data, Teknik Pengumpulan Data, Instrumen Penelitian, Teknik Analisis Data.

\subsection{Rancangan Penelitian}

Menurut Kaelan (2005:5) penelitian kualitatif adalah sebuah prosedur penelitian yang menghasilkan data deskriptif berupa kata-kata, catatan-catatan yang berhubungan dengan makna, nilai serta pengertian. Dalam penelitian ini, mendeskripsikan hasil penelitian berupa kata-kata dan informasi yang didapat dari hasil wawancara serta observasi yang ada kaitannya dengan penerapan lagu pendidikan agama Hindu dalam membentuk karakter siswa PAUD Hindu Amertha Yulia Ganesha.

\subsection{Lokasi Penelitian}

Dalam penelitian ini lokasi yang dipilih yaitu PAUD Hindu Amertha Yulia Ganesha. PAUD Hindu ini berlokasi di banjar dinas Kubakal, desa Pempatan, kecamatan Rendang, kabupaten Karangasem-Amlapura, provinsi Bali. Adapun peneliti memilih lokasi ini adalah karena PAUD Hindu Amertha Yulia Ganesha merupakan satu-satunya PAUD Hindu yang sudah mengantongi ijin pendirian PAUD Hindu dari Diektorat Jenderal Bimbingan Masyarakat Hindu Kementerian Agama Republik Indonesia di kabupaten Karangasem Bali, sehingga sekolah tersebut dipandang sangat cocok dan pantas untuk diteliti, karena berdasarkan pertimbangan bahwa permasalahan yang terjadi telah dipaparkan melalui latar belakang masalah, yang terkait lagu keagamaan Hindu dalam pembentukan karakter siswa PAUD Hindu Amertha Yulia Ganesha.

\section{GAMBARAN UMUM LOKASI PENELITIAN}

\subsection{Lokasi penelitian}

Penelitian ini dilakukan di lembaga Pratama Widya Pasraman (PWP) Amertha Yulia Ganesha, yang beralamat di Banjar Dinas Kubakal, Desa Pempatan, Kecamatan Rendang, Kabupaten Karangasem, Provinsi Bali. Pratama Widya Pasraman Amertha Yulia Ganesha merupakan lembaga PAUD Hindu yang bernaung dibawah ijin Direktorat Jenderal Bimbingan Masyarakat Hindu, Kementerian Agama Republik Indonesia. Pratama Widya Pasraman Amertha Yulia Ganesha, merupakan satu-satunya lembaga PAUD yang mengantongi ijin langsung dari Direktorat Jenderal Bimas Hindu Kementerian Agama RI di Kabupaten 
Karangasem. Lembaga PWP Amertha Yulia Ganesha dibentuk berdasarkan peraturan Menteri Agama Republik Indonesia Nomor 56 Tahun 2014 tentang Ijin pendirian dan Operasional Lembaga Hindu. PWP Amertha Yulia Ganesha, resmi mengantongi ijin operasional berdasarkan Keputusan Direktur Jenderal Bimbingan Masyarakat Hindu Nomor 177 Tahun 2016 tanggal 15 November 2016. Selain itu, PWP Amertha Yulia Ganesha juga sudah memiliki nomor Statistik Pasraman (NSP) 101251070004.

Pratama Widya Pasraman Amertha Yulia Ganesha, merupakan salah satu program kerja dari Yayasan Amertha Yulia Ganesha. Yayasan Amertha Yulia Ganesha berdasarkan akta pendirian nomor 07 Tanggal 29 Januari 2013 oleh Notaris/P.P.A.T Pejabat Pembuat Akta Tanah a.n Ida Ayu Kalpikawati, berdasarkan Keputusan Menteri Hukum dan Hak Asasi Manusia Republik Indonesia Nomor : AHU-8092.AH.01.04. Tahun 2013. Yayasan Amertha Yulia Ganesha juga sudah terdaftar di Badan Kesbang Pol dan Linmas Nomor : 220/964/hubleg/ KBPPM. Selain itu, PWP TK Amertha Yulia Ganesha juga sudah terakreditasi B oleh Badan Akreditasi Nasional Pendidikan Anak Usia Dini dan Pendidikan Non Formal (BAN PAUD dan PNF) Nomor : PAUD 5107 0000212 2016. PWP Amertha Yulia Ganesha merupakan lembaga Pendidikan Anak Usia dini yang berlokasi di daerah pedesaan, tepatnya di daerah bongkol gunung agung, namun memiliki program khusus mendidik anak Hindu yang berusia 3-6 tahun melalui program kelompok bermain dan taman kanak-kanak. PWP Amertha Yulia Ganesha memiliki visi dan misi yakni memajukan desa melalui pendidikan, terutama pendidikan anak usia dini. Terjabarkan melalui visi dan misi lembaga yakni: visi, menjadikan lembaga Pratama Widya Pasraman Amertha Yulia Ganesha sebagai lembaga percontohan bagi lembaga sejenis serta menjadi lembaga yang bermutu, berkualitas dan profesional dalam segala bidang. Sedangkan misi dari PWP Amertha Yulia Ganesha yaitu : 1) menyelenggarakan pendidikan anak usia dini yang bernuansa Hindu, 2) menyelenggarakan pendidikan anak usia dini berdasarkan kearifan lokal dan local genius setempat.

PWP Amertha Yulia Ganesha secara resmi mengantongi ijin dari Dirjen Bimas Hindu dari tahun 2016. Namun, dalam pelaksanaannya PAUD Amertha Yulia Ganesha sudah berjalan dari tahun 2012 dibawah pengawasan Dinas Pendidikan Kepemudaan dan Olahraga Kabupaten Karangasem. PAUD PWP Amertha Yulia Ganesha sudah memiliki 6 (enam) angkatan dari awal berdiri. Jumlah siswa/i yang sudah selesai mengenyam pendidikan di PAUD PWP Amertha Yulia Ganesha sebanyak 150 Peserta didik. Jumlah peserta didik tahun pelajaran terakhir sebanyak 25 peserta didik. Adapun profil lembaga PWP Amertha Yulia Ganesha secara lebih detail bisa diamati pada tabel berikut.

\begin{tabular}{|c|c|}
\hline \multicolumn{2}{|c|}{$\begin{array}{l}\text { Profil Lembaga yang Dikelola Yayasan } \\
\text { Amertha Yulia Ganesha }\end{array}$} \\
\hline Nama Lembaga & $\begin{array}{l}\text { PAUD PWP Amertha Yulia } \\
\text { Ganesha }\end{array}$ \\
\hline NPSN & 69978659 \\
\hline Alamat & $\begin{array}{l}\text { Br. Dinas Kubakal, Ds. } \\
\text { Pempatan, Kec. Rendang, } \\
\text { Kab. Karangasem- } \\
\text { Amlapura, Prov. Bali }\end{array}$ \\
\hline No. HP & $\begin{array}{l}081915699603 / 081238 \\
134236\end{array}$ \\
\hline Tahun Berdiri & 2012 \\
\hline Ijin Operasional & $\begin{array}{l}\text { 421.9/238/PNFI/PNF-PO/ } \\
\text { DISDIKPORA/2015 }\end{array}$ \\
\hline Badan Hukum & $\begin{array}{l}\text { Akta Pendirian : Yayasan } \\
\text { Amertha Yulia Ganesha } \\
\text { NotarisP.P.A.T : Ida Ayu } \\
\text { Kalpikawati, SH,SpN } \\
\text { Nomor : } 07 \text { Tanggal : } 29 \\
\text { Januari } 2013 \\
\text { SK Kemenhunkam: AHU- } \\
\text { 8092.AH.01.04. Tahun } \\
\text { 2013 }\end{array}$ \\
\hline Rekening Bank & $\begin{array}{l}\text { BRI a/n PKBM Amertha } \\
\text { Yulia Ganesha } \\
\text { Nomor : 4610-01-010495- } \\
53-3\end{array}$ \\
\hline NPWP & $31.731 .441 .7-907.000$ \\
\hline Akreditasi & $\begin{array}{l}\text { B, Nomor : PKBM } 5107 \\
00001122016\end{array}$ \\
\hline
\end{tabular}




\section{PENERAPAN LAGU}

KEAGAMAAN HINDU DALAM

MEMBENTUK KARAKTER

SISWA PAUD HINDU AMERTHA

YULIA GANESHA

Lagu keagamaan Hindu dirancang untuk mengubah mindset peserta didik, yang semakin hari semakin kecanduan dengan gadget/HP. Untuk meminimalisir kemungkinan adanya efek negatif HP dan konten-konten negatif lainnya diperlukan suatu strategi yang unik, menyenangkan dan mudah diingat. Salah satunya adalah kemasan materi yang dibalut dengan melodi menjadi lagu keagamaan Hindu yang diperuntukkan untuk anak-anak terutama peserta didik PAUD. Misalnya dalam mengajarkan konsep Tri Hita Karana dalam usaha menjaga keharmonisan antara manusia dengan Pencipta, Manusia dengan sesama manusia serta manusia dengan alam semesta.

Menurut informasi dari Pendidik PAUD Hindu Amertha Yulia Ganesha, Ni Kadek Puri Puspawati (Wawancara, tanggal 27 Juni 2018) menyatakan bahwa lagu keagamaan sangat efektif dalam usaha mengajarkan materi dan menanamkan nilainilai karakter kepada peserta didik. Hal ini dikeranakan lagu yang dibuat sangat sederhana, liriknya mudah diingat, dan pendek-pendeknya. Lagu keagamaan yang diajarkan adalah lagu keagamaan yang benar-benar baru dan dikemas sedemikian rupa menyesuaikan dengan umur anak. Selain mengajarkan Tri Hita Karana, lagu keagamaan yang dibuat juga tentang semua hal yang umum harus diketahui oleh anak dari sejak dini. Diantaranya tentang Tri Kaya Parisudha, Catur Guru, Panca Sembah, Sarana Persembahyangan, Bangga Menjadi Anak Bali, Bangga Beragama Hindu, dan sebagainya.

Proses pembelajaran di PAUD Hindu Amertha Yulia Ganesha, sebagian besar memang didesain dengan pengkolaborasian antaranyanyian, permainan, dan pembelajaran di dalam maupun di luar kelas dengan bantuan APE (alat permainan edukatif). I Komang
Budiasa (guru PAUD Hindu Amertha Yulia Ganesha) menambahkan, anak didik sangat senang belajar jika guru-gurunya kreatif dalam menyajikan pembelajaran. Pembelajaran yang dikemas sedemikian rupa yang didesain melalui perencanaan pembelajaran harian/ RPPH, dengan menyesuaian tema dan sub tema dari Rencana Pelaksanaan Pembelajaran mingguan/RPPM, adalah suatu cara untuk mencapai indikator dan tujuan pembelajaran berdasarkan standar kompetensi dan kompetensi yang diamanatkan dalam kurikulum pendidikan anak usia dini. Pembelajaran di PAUD Hindu Amertha Yulia Ganesha $60 \%$ berupa materi tentang keagamaan Hindu dan $40 \%$ nya adalah materi yang bersifat umum mengacu pada kurikulum Pusat yang tertuang dalam Permendikbud Nomor 146 Tahun 2014 tentang kurikulum 2013 pendidikan anak usia dini.

Berdasarkan proses perekaman harian, mingguan, bulanan yang dilaksanakan oleh peneliti, dijumpai memang pendidik PAUD Hindu Amertha Yulia Ganesha, sangat serius dalam mendidik dan mengasuh peserta didiknya. Teramati jam pelajaran yang dimulai dari pukul 07.30 wita sampai dengan pukul 10.30 wita, Pendidik sudah hadir di sekolah pukul 06.30 wita, sambari melakukan pembersihan keliling lembaga PAUD, dan mempersiapkan segala kelengkapan yang sekiranya dapat menunjang proses belajar mengajar di lembaga PAUD. Begitu anak dating ke sekolah, Para pendidik terlihat sudah siap menunggu anak di depan sekolah dan menyapa anak dan orang tua anak dengan sapaan Om Swastyastu dan selamat pagi.begitu pula dengan peserta didik yang sudah ditunggu oleh Bapak dan Ibu gurunya juga Nampak sangat antusias mengucapkan salam Om Swastyastu dan mengecup tangan para gurunya. Beberapa nilai-nilai karakter sudah nampak tumbuh dan berkembang seperti: religius, toleransi, disiplin, mandiri, bersahabat/komunikatif, cinta damai, peduli social dan tanggung jawab. 
6. TUJUAN DAN FUNGSI LAGU KEAGAMAAN HINDU DALAM PEMBENTUKAN KARAKTER SISWA PAUD AMERTHA YULIA GANESHA

Lagu merupakan gubahan seni nada atau suara dalam urutan, kombinasi, dan hubungan temporal (biasanya diiringi dengan alat musik) untuk menghasilkan gubahan musik yang mempunyai kesatuan dan kesinambungan (mengandung irama). Ragam nada atau suara yang berirama disebut juga dengan lagu. Lagu dapat dinyanyikan secara solo, berdua (duet), bertiga (trio) atau lebih dari tiga (Choir). Perkataan dalam lagu biasanya berbentuk puisi berirama, namun ada juga yang bersifat keagamaan ataupun prosa bebas. Lagu dapat dikategorikan pada banyak jenis, bergantung kepada ukuran yang digunakan. Dalam lagu dapat memberi suasana dan emosional serta syair dari lagu tersebut dapat menjadi pembelajaran untuk anak-anak.

Pembelajaran di lembaga PWP Amertha Yulia Ganesha didesain sedemikian rupa dengan penerapan lagu-lagu keagamaan Hindu namun tetap memperhatikan adanya perubahan karakter masing-masing peserta didik. Lagu keagamaan Hindu diberikan di awal pembelajaran, di kegiatan inti dan di kegiatan penutup. Di awal pembelajaran, untuk mengingatkan kembali tentang lagu yang diajarkan pada pertemuan sebelumnya. Berdasarkan wawancara yang dilakukan oleh Peneliti kepada beberapa guru dan orang tua siswa terkait perubahan karakter setelah anak didik diberikan lagu-lagu keagamaan Hindu, memang terjadi perubahan yang cukup signifikan terhadap perubahan perilaku anak didik. Anak didik PWP Amertha Yulia Ganesha mulai ingat waktuwaktu sembahyang, suka beryadnya, dan lain sebagainya.

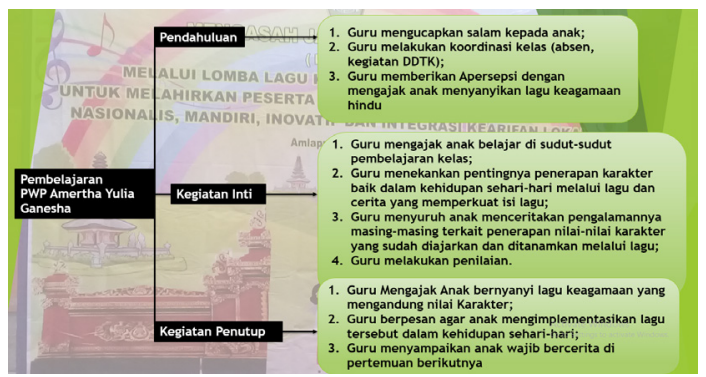

Pembelajaran yang dilakukan oleh guru, tidak harus berada di dalam kelas. Pembelajaran di Pratama Widya Pasraman/ PAUD Hindu, bisa diselenggarakan di halaman sekolah, area bermain, padmasana, dan di lingkungan sekitar yang tentunya aman dan menyenangkan bagi peserta didik.

Lagu waktu berdoa, dimaksudkan untuk mengingatkan anak tentang waktuwaktu yang harus mereka ketahui tentang jam berdoa mereka. Sesuai dengan waktu untuk melakukan Puja Tri Sandhya yang juga wajib dilakukan sebanyak tiga kali dalam sehari (pagi, siang dan sore hari), banyak masyarakat yang justru sering lupa melakukannya. Dengan penanaman konsep dari usia dini, diharapkan dibenak anak didik sudah tertanam konsep yang baik tentang waktu bersembahyang. Begitu pagi hari sebelum berangkat kesekolah anak sudah berdoa di rumahnya/sanggah kemulan, pulang sekolah anak kembali melakukan tri sandhya/berdoa sebelum pulang, kemudian sore hari setelah selesai mandi anak didik juga secara spontan berdoa/bersembahyang. Konsep seperti inilah yang harus terus ditanamkan oleh Pendidik maupun orang tua siswa dalam rangka menumbuhkan karakter religius bagi anak didik.

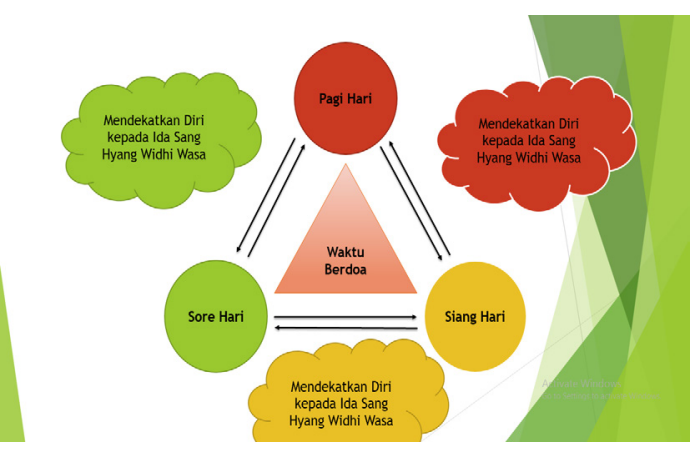

Penelitian yang dilakukan, sangatlah memperhatikan perubahan tingkah laku dari peserta didik yang diteliti. Dalam hal ini peneliti selalu menggunakan pendekatan Tanya jawab, dan wawancara yang tentunya dibarengi dengan kegiatan bermain. Tidak hanya itu, peneliti juga selalu mengadakan wawancara kepada pendidik dan orang tua siswa, guna mendapatkan informasi yang benar-benar valid tentang keberhasilan 
menggunakan lagu keagamaan Hindu. Lagu keagamaan Hindu diharapkan mampu menjadi jawaban dari masalah yang kerap menghantui permasalahan yang dialami oleh anak usia dini.

Widia Pekerti (Metode Pengembangan Seni : 2017, 58) menjelaskan bahwa musik memiliki fungsi : (1) digunakan untuk hiburan, (2) sebagai media menyampaikan informasi/pendidikan, (3) digunakan pada upacara penaikan bendera, ibadah, kelahiran, kematian, pernikahan, panen, dan keperluan upacara lain. (4) digunakan sebagai tontonan (performance) karena para seniman ingin mendengarkan karya ciptaannya dengan jalan memainkan atau menyanyikan music. (5) dipergunakan untuk penyembuhan yang disebut juga terapi dengan lagu/music. (6) digunakan pada pengembangan teknologi, antara lain pada bidang tanaman, dan sebagainya. (7) memperkenalkan nilai-nilai karakter, lewat kemasan syair yang dibuatkan nada. (8) dan lain sebagainya.

Menurut salah satu Pakar Pendidikan, Iskandar (2010:5) menyatakan bahwa pendidikan merupakan proses yang terjadi secara terus menerus (abadi) dari penyesuaian yang lebih tinggi bagi manusia yang telah berkembang secara fisik dan mental, yang bebas dan sadar kepada Tuhan. Nilai-nilai pendidikan karakter adalah suatu makna dan ukuran yang tepat dan akurat yang mempengaruhi adanya pendidikan itu sendiri. Ada 18 pendidikan karakter yang wajib diketahui antara lain (1) Religius, (2) Jujur, (3) toleransi, (4) disiplin, (5) kerja keras, (6) kreatif, (7) mandiri, (8) demokratis, (9) rasa ingin tahu, (10) semangat kebangsaan, (11) cinta tanah air, (12) menghargai prestasi, (13) bersahabat/komunikasi, (14) cintai damai, (15) gemar membaca, (16) peduli lingkungan, (17) peduli sosial, dan (18) tanggung jawab. Kemasan Pendidikan karakter yang didesain sedemikian rupa menjadi lagu-lagu keagamaan anak Hindu, memungkinkan dapat meminimalisir penyimpanganpenyimpangan tersebut. Dengan catatan setelah guru memberikan anak didik lagu keagamaan, guru wajib mmberikan penekanan kembali berupa contoh sikap atau dongeng yang sekiranya mampu memberikan bayangan kepada peserta didik untuk tidak mengulangi hal-hal menyeimpang tersebut. Salah satu lagu yang terbukti ampuh dalam pembelajaran adalah lagu "Ciri-Ciri Anak Baik"

\section{TANGGAPAN MASYARAKAT TERHADAP PENERAPAN LAGU KEAGAMAAN HINDU DALAM PEMBENTUKAN KARAKTER SISWA PAUD HINDU AMERTHA YULIA GANESHA}

Penerapan lagu keagamaan Hindu untuk membentuk karakter siswa sangatlah penting untuk masa depan generasi muda Indonesia, dalam membentuk karakter yang baik pada siswa yang membutuhkan peran guru, orang tua dan masyarakat. Peran sekolah yang dalam hal ini PAUD Hindu Amertha Yulia Ganesha adalah menyinergikan keluarga dan masyarakat untuk berperan aktif dalam pendidikan terutama dalam penguatan pendidikan karakter. PAUD Hindu Amertha Yulia Ganesha memiliki komitmen dalam membentuk karakter siswa menjadi generasi yang mampu mengamalkan ajaran agamanya melalui lagu keagamaan Hindu yang diciptakan sendiri, dimana lirik dan katanyakatanya mengandung unsur pendidikan karakter dan nilai-nilai agama Hindu. Hal tersebut menjadikan PAUD Hindu Amertha Yulia Ganesha dipercayai oleh masyarakat dalam menanamkan pendidikan karakter melalui pembiasaan yang baik, sehingga PAUD Hindu Amertha Yulia Ganesha telah banyak mendapatkan respons dan tanggapan positif dari orang tua yang menyekolahkan anaknya di PAUD Hindu Amertha Yulia Ganesha.Berdasarkan dari hasil pengamatan dan wawancara secara mendalam terhadap orang tua, guru, dan siswa mengenai penerapan lagu keagamaan Hindu dalam upaya pembentukan karakter di PAUD Hindu Amertha Yulia Ganesha, menunjukkan adanya perubahan perilaku yang dialami peserta didik. Perubahan perilaku siswa tersebut mendapatkan beberapa tanggapan dari orang tua dan pendidik PAUD Hindu Amertha Yulia Ganesha. Hal tersebut akan dipaparkan sebagai berikut. 
7.1 Respon Orang Tua terhadap Penerapan Lagu Keagamaan Hindu

Berpedoman pada daftar pertanyaan, peneliti mengajukan pertanyaan untuk memperoleh tanggapan dari orang tua siswa terhadap penerapan lagu keagamaan Hindu terhadap pendidikan karakter di PAUD Hindu Amertha Yulia Ganesha. Pada table di atas terdapat jumlah informan sebanyak lima orang yang menyatakan tanggapan yang hampir sama. Berikut ini adalah hasil wawancara kepada informan perihal penerapan lagu keagamaan Hindu terhadap peningkatan pendidikan karakter di PAUD Hindu Amertha Yulia Ganesha. Informan pertama dari I Wayan Nubagia (wawancara 31 Juli 2018) sebagai berikut. "Sebagai orag tua, saya merasa bangga karena setelah anak saya bersekolah di PAUD Hindu Amertha Yulia Ganesha, banyak hal positif yang kini mulai dilakukan oleh anak saya. Salah satunya adalah anak saya selalu berdoa ketika baru akan berangkat kesekolah, rajin mengucapkan gayatri mantram, dan senantiasa selalu mau memungut sampah yang ditemuinya dan dibuang di tempat sampah. Anak saya juga kadang-kadang sudah mampu menunjukkan sikap mandirinya, terlihat dari sudah mampu makan sendiri dan mandi sendiri. Serta ketika saya melakukan kegiatan bersih-bersih rumah, anak saya secara spontan ikut membantu kegiatan bersih-bersih. Secara pribadi saya sangat bangga dengan perkembangan anak saya dari sbelum bersekolah dan setelah bersekolah di PAUD Hindu Amertha Yulia Ganesha".

Respon yang hampir sama juga ditunjukkan oleh informan ke dua yaitu, I Wayan Selamat (Wawancara, 1 Agustus 2018) sebagai berikut: "Saya sangat kagum dengan metode mengajar yang diterapkan oleh pendidik di PAUD Hindu Amertha Yulia Ganesha dengan mengkolaborasikan antara pembelajaran dengan nyanyian dan permainan, anak saya sangat senang dalam belajar. Anak saya yang tadinya harus ditunggu sampai pulang sekolah, kini justru meminta saya untuk pulang dan menjemputnya ketika sudah pulang sekolah. Anak saya mengaku, sangat senang belajar di PAUD Hindu Amertha Yulia Ganesha, karena
Bapak dan Ibu gurunya baik-baik. Anak saya juga nampak sudah mau bergaul dengan temannya yang lain, serta mau mengerjakan tugas yang diberikan oleh gurunya. Baik tugas yang diberikan di sekolah maupun tugas yang meski dikerjakan di rumah. Perkembangan ini tidak bisa terlepas dari peran guru yang mengajar dan metode yang diterapkan oleh guru di PAUD Hindu Amertha Yulia Ganesha. Apalagi melalui lagu "ciri-ciri anak baik" yang diajarkan dan ditanamkan oleh gurunya, anak saya sudah mampu membedakan mana sikap baik dan buruk, menurut pengakuan anak saya, kalau rajin bersembahyang itu adalah sikap baik, kalau malas adalah sikap kurang baik. Itulah kebanggaan saya ketika menyekolahkan anak saya di PAUD Hindu Amertha Yulia Ganesha.

\subsection{Respon Guru terhadap Penerapan Lagu Keagamaan Hindu}

Berdasarkan hasil wawancara dengan kepala sekolah dan guru PAUD Hindu Amertha Yulia Ganesha terhadap penerapan lagu keagamaan hindu dalam pembentukan karakter siswa PAUD Hindu Amertha Yulia Ganesha, terdapat beberapa respon dari kepala sekolah dan guru sebagai berikut. Respon pertama diungkapkan oleh Ni Kadek Eni Mahayanti, S.Pd (wawancara, tanggal 10 Agustus 2018) sebagai berikut: "Sebagai kepala sekolah, saya selalu menekankan pada guru-guru di PAUD Hindu Amertha Yulia Ganeshauntukselalumenanamkanpendidikan karakter di setiap proses pembelajaran, dari kegiatan awal sampai kegiatan akhir pembelajaran. Pendidikan karakter yang ditanamkan meliputi, pengucapan salam di awal pembelajaran, kegiatan doa bersama, pembersihan lingkungan kelas, kegiatan pada kegitan inti pembelajaran, dan salam saat pulang sekolah. Kegiatan-kegiatan seperti ini, bertujuan untuk membiasakan siswa melakukan kegiatan-kegiatan yang positif. Di PAUD Hindu Amertha Yulia Ganesha, setelah dikolaborasikan dengan lagu keagamaan hindu dan kegiatan mendongeng, siswa lebih paham tentang hal-hal yang boleh dilakukan dan hal-hal yang meski dijauhi. Melalui penanaman karakter dengan lagu tri kaya parisudha dan ciri-ciri anak baik, 
pendidik menekankan pada hal-hal baik yang sekiranya selalu dipupuk dan hal-hal yang tidak baik, yang sekiranya harus dikurangi dan tidak dilakukan untuk mencapai sebuah kebahagiaan. Sejauh ini, beberapa hal positif sudah mampu dilakukan oleh anak-anak siswa PAUD Hindu Amertha Yulia Ganesha, mudah-mudahan dengan kebiasaan yang terus diulang-ulang siswa PAUD Hindu Amertha Yulia Ganesha akan tumbuh menjadi tunas-tunas yang berkarakter dan beretika". Respon kedua diungkapkan oleh I Komang Budiasa, S.Pd., Guru PAUD Hindu Amertha Yulia Ganesha (Wawancara,13 Agustus 2018) sebagai berikut. "Sebagai seorang guru dalam membentuk karakter anak usia dini merupakan hal yang sangat penting karena anak usia dini dikenal sebagai pondasi awal dari terbentuknya karakter yang baik. Untuk menanamkan pendidikan karakter pada siswa disini mmbutuhkan waktu yang tidak sebentar dan juga membutuhkan kesabaran dalam memberikan pendidikan karakter. Jadi saya berusaha menjadi murid teladan bagi siswa saya, agar mereka dapat mengikuti setiap contoh perilaku baik yang saya terapkan". Respon ketiga diungkapkan oleh Ni Nengah Wenten Pendidik PAUD Hindu Amertha Yulia Ganesha (Wawancara, 15 Agustus 2018) sebagai berikut. "Pembelajaran di PAUD Hindu Amertha Yulia Ganesha tidak hanya menekankan pada pembelajaran yang bersifat intelektual. Namun harus diimbangkan dengan pembelajaran yang berkaitan dengan pendidikan karakter. Pendidikan karakter yang dikemas melalui lagu keagamaan Hindu, sangat mempermudah siswa dalam belajar. Penguasaan kosa kata anak terhadap istilah-istilah Hindu juga semakin banyak. Anak mulai diperkenalkan dengan istilah salam om swastyastu, tri murti, tri kaya parisudha, tri hita karana, dan yang lainnya. Sampai saat ini, PAUD Hindu Amertha Yulia Ganesha telah mendapatkan kepercayaan yang tinggi dari masyarakat, selain dikenal sebagai sekolah Hindu, PAUD Hindu Amertha Yulia juga dikenal sebagai lembaga yang berprestasi sering melibatkan peserta didiknya diberbagai ajang lomba". Berdasarkan hasil wawancara dengan kepala sekolah dan pendidik PAUD Hindu Amertha
Yulia Ganesha dapat disimpulkan beberapa hal, seperti : dalam menanamkan pendidikan karakter melalui lagu keagamaan Hindu, hal pertama yang harus dilakukan oleh pendidik PAUD Hindu Amertha Yulia Ganesha adalah selalu memperhatikan setiap perkembangan yang dimiliki oleh siswa.

\subsection{Respon Siswa terhadap Penerapan Lagu Keagamaan Hindu}

Berdasarkan hasil wawancara dengan siswa mengenai suasana belajar di PAUD Hindu Amertha Yulia Ganesha. Terdapat beberapa respon dari siswa sebagai berikut. Respon pertama diungkapkan oleh $\mathrm{Ni}$ Luh Selvi Vanesha (Wawancara tanggal 10 Agustus 2018) sebagai berikut. "Saya senang sekolah di PAUD Hindu Amertha Yulia Ganesha, karena banyak ada mainan, dan banyak teman. Guru sering ngajarin nyanyi dan mewarnai. Guru selalu mengajari menjaga kebersihan kuku dan kelas". Respon kedua diungkapkan oleh siswa Ni Ketut Dewi Mertini (wawancara tanggal 13 Agustus 2018) sebagai berikut. Saya senang bersekolah di PAUD Hindu Amertha Yulia Ganesha. Ibu guru sering menceritakan dongeng dan lagu-lagu bagus. Setiap pagi diajak senam dan bermain. Bapak dan Ibu guru selalu mengajarkan tentang bersyukur kepada Tuhan dan berdoa. Berdasarkan hasil wawancara dengan siswa PAUD Hindu Amertha Yulia Ganesha dapat disimpulkan dari beberapa tanggapan tersebut bahwa, siswa merasa senang bersekolah di PAUD Hindu Amertha Yulia Ganesha, karena selain mempunyai banyak teman dan banyak mainan. Siswa juga merasa senang karena memiliki guruguru yang baik. Berdasarkan hasil penelitian dari lapangan melalui analisis data, penulis menemukan keterkaitan teori Resepsi dalam menganalisis respon masyarakat terhadap penerapan lagu keagamaan hindu dalam membangun karakter siswa PAUD Hindu Amertha Yulia Ganesha. Berdasarkan penjelasan dari teori resepsi dapat dipahami bahwa, objek dari penelitian ini adalah siswa itu sendiri, dalam membentuk karakter siswa yang baik terhadap siswa PAUD Hindu Amertha Yulia Ganesha. Salah satu cara yang diterapkan oleh guru PAUD Hindu Amertha 
Yulia Ganesha dalam membentuk karakter siswa dengan lagu keagamaan Hindu. Selain itu, dalam membentuk karakter siswa, guru mengajarkan siswa agar selalu bersyukur kepada Tuhan Yang Maha Esa dengan menggunakan metode menyanyi.

\section{PENUTUP}

\subsection{Simpulan}

Berdasarkan dari hasil penelitian di lapangan melalui observasi, wawancara, dan dokumentasi, penulis dapat menyimpulkan mengenai lagu keagamaan Hindu dalam pembentukan karakter siswa PAUD Hindu Amertha Yulia Ganesha banjar dinas Kubakal, desa Pempatan, kecamatan Rendang, kabupaten Karangasem, provinsi Bali sebagai berikut. Karena lagu keagamaan Hindu dalam membentuk karakter siswa PAUD Hindu Amertha Yulia Ganesha adalah dapat menanamkan nilai-nilai karakter, dan nilai-nilai agama Hindu pada siswa, dengan penerapan lagu keagamaan Hindu yang dikolaborasikan dengan pembelajaran yang menyenangkan dan bermakna secara tidak langsung akan mengembangkan karakter dan penguasaan istilah-istilah keagamaan Hindu bagi anak usia dini. Nilai-nilai agama Hindu ini akan membentuk kepribadian yang baik sekaligus pembentukan karakter positif bagi anak. Nilai-nilai pendidikan karakter dan nilai-nilai agama Hindu yang dapat ditransformasikan melalui ajaran agama Hindu, yaitu salah satu bagian dari Tri Kaya Parisudha adalah ajaran Kayika (perbuatan yang baik), wacika (perkataan yang baik), dan manacika (pikiran yang baik). Selain itu, dengan mengajarkan siswa mengucapkan $\mathrm{Om}$ Swastyastu, dan mengajarkan siswa untuk selalu melaksanakan persembahyangan. Selain dapat menanamkan nilai-nilai agama Hindu, lagu keagamaan agama Hindu juga dapat mengembangkan nilai-nilai moral bagi siswa yaitu dengan mengajarkan tentang bagaimana bersikap baik, bertingkah laku yang baik, serta mengajarkan siswa untuk selalu berbicara yang sopan di tengahtengah masyarakat. Lagu pendidikan agama Hindu dalam mengembangkan moral bagi anak usia dini memberikan dampak positif terhadap siswa PAUD Hindu Amertha Yulia Ganesha. Hal positif yang didapatkan dari pengembangan pendidikan karakter melalui lagu keagamaan Hindu antara lain (1) siswa dapat berbicara sopan, (2) siswa dapat mengucapkan salam Om Swastyastu dan Om Santih Santih Santih Om, (3) siswa belajar menggunakan tangan kanan, (4) siswa belajar menjaga kebersihan diri, hati, dan lingkungan, (4) siswa berdoa sebelum makan, (5) siswa melakukan pua gayatri Mantram sebelum pembelajaran dan pulang sekolah.

\subsection{Saran}

Berdasarkan hasil penelitian tersebut, penulis perlu memberikan saran kepada siswa PAUD Hindu Amertha Yulia Ganesha, guru TK Amertha Yulia Ganesha dan peneliti mengenai lagu keagamaan hindu dalam pembentukan karakter siswa PAUD Hindu Amertha Yulia Ganesha sebagai berikut: (1) Kepada siswa PAUD Hindu Amertha Yulia Ganesha, agar dapat selalu mengamalkan setiap ajaran agama Hindu dalam kehidupan sehari-hari, sehingga dapat terbentuknya karakter suputra; (2) Kepada guru PAUD Hindu Amertha Yulia Ganesha, agar mampu memberikan motivasi kepada siswa dalam mengubah perilaku dari yang tidak baik menjadi baik serta memotivasi siswa agar selalu melakukan pembiasaan-pembiasaan yang telah diajarkan oleh guru PAUD Hindu Amertha Yulia Ganesha.

\section{DAFTAR PUSTAKA}

Andani.2016. Siswa PAUD babak belur dianiaya anak TK B. Jawa Timur: Jawa Pos.com

Anonim, 2008. Kamus Besar Bahasa Indonesia Pusat Bahasa.Jakarta: Gramedia.

Pustaka Utama Arikunto, S. 2005. Dasardasar Evaluasi Pendidikan (Edisi Revisi). Jakarta: PT Bumi Aksara

Arikunto, Suharsimi.2002. Prosedur Penelitian Suatu Pendekatan Praktek. Yogyakarta:Rineka Cipta. 
Bungin, Burhan.2001. Metode Penelitian Sosial Format-Format Kualitatif dan Kuantitatif. Surabaya: Airlangga.

Dantes. 2009. Pendidikan Profesi Guru dalam Kaitannya dengan Peningkatan Profesionalisme Guru (Refleksi Tentang Struktur Program LPTK). Makalah disampaikan dalam seminar LPTK.

Departemen Pendidikan Nasional. 2002. Pembelajaran Kontekstual. Jakarta.

Dian, Noviyanti. 2014. Anak-Anak Kita Pengukir Peradaban. Jakarta: PT. Elex Media Komputindo. Kompas Gramedia.

Gegne, R. M. 1970. The Condition of Learning. New York.

Hasan, M. Iqbal.2002. Pokok-pokok Materi Metodologi Penelitian dan Aplikasinya. Bogor: Ghalia.

Jasmine, Grace. 2005. Taktik Quick \& Fun Games For Kids. Terjemahan Edi Santoso. Yogyakarta: Bookmarks.

Kadir, Abdul. 2012. Dasar-dasar Pendidikan. Jakarta: Kencana.

Kaelan. 2005. Metode Penelitian Kualitatif Bidang Filsafat. Yogyakarta: Paradigma.

Kamus Lengkap Bahasa Indonesia. Gita Media Press. Mitra Pressindo.

Kemdikbud.2016.PanduanPenyelenggaraan Penilaian Akhir Pendidikan Keaksaraan Dasar. Jakarta: Direktorat Pembinaan Pendidikan Keaksaraan dan Kesetaraan Direktorat Jenderal Pendidikan Anak Usia Dini dan Pendidikan Masyarakat Kementerian Pendidikan dan Kebudayaan.

Kertamuda. M.A. 2015. Golden age strategi Sukses Membentuk Karakter Emas Pada Anak Sejak Usia Dini. Jakarta: PT Elex Media Komutindo. Kompas Gramedia.
Koentjaraningrat.1978. Metode-metode Penelitian Masyarakat. Jakarta: Gramedia.

Lasmawan. 2009. Meretas Keindonesiaan dalam Bingkai Tirani Minoritas, makalah disampaikan pada sidang terbuka orasi pengenalan jabatan Guru Besar Tetap dalam bidang IPS Undiksha pada tanggal 31 Oktober 2009.

Latif.M, dkk. 2014. Orientasi Baru Pendidikan Anak Usia Dini Teori dan Aplikasi. Jakarta: Kencana. Prenadamedia Group.

Malahayati. 2009. 50 Permainan Melatih Kecerdasan Anak. Surabaya: Nusantara Publisher.

Miller. Hugh. 2017. Apresiasi Musik. Yogyakarta: Thafa Media.

Moleong, Lexy. 2004. Metode penelitian Kualitatif. Bandung: Remaja Rosda Karya.

Munnir, Abdullah. 2011. Super Teacher Sosok Guru yang dihormati, Disegani, dan Dicintai. Yogyakarta: Pedagogia.

Nawawi, Hadari. 2005. Metode Penelitian Bidang Sosial. Jakarta: Dian Rakyat.

Nisak, Raisatun. 2011. 50 Game Kreatif untuk Aktivitas Belajar Mengajar. Yogyakarta: Diva Press. Sampangan.

Nurdin, Muhammad. 2004. Kiat Menjadi Guru Profesional. Yogyakarta; Prisma Sophie.

Paramartha, Wayan. 2015. Orasi Ilmiah: Revolusi Mental Melalui Internalisasi Nilai-Nilai Pendidikan Agama Hindu dalam Pembentukan Karakter Bangsa. Denpasar.

Peraturan Menteri Agama Republik Indonesia Nomor 56 Tahun 2014 tentang Pendidikan Keagamaan Hindu.

PHDI. 1997/1998. Himpunan Keputusan Kesatuan Terhadap Aspek Agma Hindu I-XV. Proyek Peningkatan Pasraman dan Sarana Kehidupan Bangsa. Denpasar. 
Purnomo, wahyu. 2010. Terampil Musik. Jakarta: Kemdiknas

Raho, Bernard. 2007. Teori Sosiologi Modern. Jakarta: Prestasi Pustaka.

Rako, J.R. 2010. Metode Penelitian Kualitatif Jenis Karakter dan Keunggulannya. Jakarta: PT Gramedia Wiya Sarana.

Sandika, Ketut. 2014. Membentuk Siswa Berkarakter Mulia Melalui Pola Pembelajaran Pendidikan Agama Hindu. Denpasar: Paramitha.

Santyasa.I.W. 2005. Implementasi Pembelajaran Inovatif dalam Praktek Pengalaman Lapangan. Makalah, disajikan dalam pembekalan awal pelaksanaan Program Hibah Kemitraan LPPL IKIP Negeri Singaraja dengan Sekolah Laboratorium IKIP Negeri Singaraja Tanggal 18-20 Juli 2005, di Singaraja.

Satori, Djam'an dan Komariah Aan. 2009. Metodologi Penelitian Kualitatif. Bandung: Alfabeta.

Sudono, Anggani. 2000. Sumber Belajar dan Alat Permainan untuk Pendidikan Anak usia Dini. Jakarta: Grasindo.

Sugiarta. 2012."Pola Penanaman Nilai-Nilai Pendidikan Agama Hindu pada Anak Usia Dini di Taman Kanak-Kanak Hindu Widya Kerthi". Skripsi. (Tidak Diterbitkan). Denpasar: Program Pendidikan Agama Hindu UNHI Denpasar.

Surviani, Istanti, dkk. 2004. 20 Point Penting dalam Menghias Jiwa \& Perilaku Anak. Bandung: Pustidaka Ulumuddin.

Suryanto, Slamet. 2005. Dasar-Dasar Pendidikan Anak Usia Dini. Jakarta: PT. Indeks.

Susanto, Ahmad. 2015. Bimbngan dan Konseling di Taman Kanak-Kanak. Jakarta: Kencana.

Tedjasaputra, M.S. 2001. Bermain, Mainan, dan Permainan. Jakarta: PT Gramedia Widia sarana Indonesia.

Thobroni. 2016. Belajar dan Pembelajaran:
Teori dan Praktek. Yogyakarta: ArRuzz Media.

Tim Gunung Djati. 2008. Memahami Musik dan Suara. Cirebon: CV. Gunung Djati.

Tim Penyusun, 2009. Peraturan. Denpasar: Widya Dharma.

Tim Penyusun, 2010. Pedoman Penulisan Usulan Penelitian Tesis dan disertasi. Denpasar: Program Pasca Sarjana Universitas Hindu Indonesia.

Trianto, M.Pd. 2008. Mendesains Pembelajaran Kontekstual di Kelas. Jakarta: Kencana Prenada Media Group.

Wibowo, Agus. 2012. Pendidikan Karakter Usia Dini (Strategi Membangun Karakter di Usia Emas). Yogyakarta: Pustaka Belajar.

Widia, Pekerti. 2017. Metode Pengembangan Seni. Jakarta: Universitas Terbuka.

Wirama, Made. 2014. "Peranan Pendidikan Anak Usia Dini dalam Menyiapkan Generasi Hindu yang Berkarakter Melalui Pendidikan Keagamaan Hindu di PAUD Kumara Dharma Kerti II". Tesis (Tidak Diterbitkan). Denpasar: Program Pasca Sarjana UNHI.

Yulianti, R. 2011. Permainan yang Meningkatkan Kecerdasan Anak Modern dan Tradisional. Jakarta: Laskar Aksara. 